УДК [378.147.091.12.011.3-051:373.3]:378.018.43

DOI:

Оксана Шквир, доктор педагогічних наук, доцент, професор кафедри педагогіки Хмельницької гуманітарно-педагогічної академії Ірина Гайдамашко, кандидат педагогічних наук, доцент кафедри педагогіки Хмельницької гуманітарно-педагогічної академії

\title{
ПІДГОТОВКА МАЙБУТНІХ УЧИТЕЛІВ ПОЧАТКОВОЇ ШКОЛИ ДО ДИСТАНЦИЙНОГО НАВЧАННЯ
}

У статті акцентовано увагу на проблемі підготовки майбутніх учителів початкової школи до дистанційного навчання як важливої форми організацї навчання сучасних молодших школярів. Уточнено сутність поняття “дистанційне навчання”. Запропоновано авторське визначення поняття “підготовка майбутніх учителів початкової школи до дистанційного навчання”. Визначено педагогічні умови підготовки майбутніх учителів початкової школи до дистанційного навчання в початковій школі. Окреслено спеціальні техніко-педагогічні знання, якими мають оволодіти майбутні вчителі початкової школи, та запропоновані иляхи їх засвосння студентами.

Ключові слова: дистанційне навчання; майбутні учителі початкової иколи; підготовка майбутніх учителів початкової школи до дистанційного навчання; техніко-педагогічні знання; контекстний підхід; електронний спецкурс.

Рис. 1. Табл. 1. Лім. 11.

Oksana Shkvyr, Doctor of Sciences (Pedagogy), Associate Professor, Professor of the Pedagogy Department Khmelnytskiy Humanitarian-Pedagogical Academy Iryna Haydamashko, Ph.D.(Pedagogy), Associate Professor of the Pedagogy Department Khmelnytskiy Humanitarian-Pedagogical Academy

\section{PREPARATION OFTHE FUTURE PRIMARY SCHOOL TEACHERS FOR DISTANCE LEARNING}

The article focuses on the problem of preparing future primary school teachers for distance learning as an important form of education organization of modern primary school pupils. The essence of the concept "distance learning" has been specified. The objective and peculiarities of distance learning have been determined. The author's definition of the concept "preparation of the future primary school teachers for distance learning" has been proposed: a system of scientifically sound actions in the educational process of higher education institution, aimed at developing the students' technical literacy; needs for self-improvement; mastering a set of special technicalpedagogical knowledge and skills, which ensures high effectiveness of the teacher's educational activities in the distance format. According to the results of studying the scientific and pedagogical literature; survey of primary school teachers, teachers of higher education institutions (HEIs); the use of methods of expert assessments and ranking, pedagogical conditions for preparing future primary school teachers for distance learning in primary school have been determined, they are: mastering by the future teachers of distance learning in primary school during the study of academic disciplines, creating educational-information environment in HEI, formation of practical skills during different types of practice, the development of the need for self-improvement. Special technical and pedagogical knowledge to be acquired by the future primary school teachers has been outlined. It is proved that the success of the students' acquisition of distance learning knowledge should be ensured by introducing a contextual approach to the training of the future primary school teachers. The matrix has been developed that reflects the inclusion of the system of distance learning knowledge into the process of studying pedagogical disciplines of bachelors and masters in the specialty 013 Primary Education. The objective and peculiarities of the introduction of the electronic special course "Methods of Distance Learning in Primary School" have been determined. It is noted that the issue of substantiation of the mentioned pedagogical conditions and the development of educational and methodological support for the preparation of the future primary school teachers for distance learning requires further scientific researches.

Keywords: distance learning; future primary school teachers; preparation of the future primary school teachers for distance learning; technical and pedagogical knowledge; contextual approach; an electronic special course. 
концептуальні положення щодо змісту й організації дистанційного навчання грунтуються на засадах законів України “Про Національну програму інформатизаціі” (1998), “Про освіту” (2017), Концепції розвитку дистанційної освіти в Україні (2000), положень про дистанційне навчання (2013) та інституційну форму здобуття загальної середньої освіти (2019). Із 2009 р. розпочалися експерименти щодо впровадження дистанційного навчання у закладах загальної середньої освіти різних регіонів України, відкривалися школи дистанційного навчання в Києві та Харкові [6; 7].

Окрім того, актуальним стало навчання на відстані у зв'язку із ситуацією в окупованому Криму, а також Донецькій та Луганській областях. У 2016 р. було створено освітній портал E-school, на якому учні тимчасово окупованих територій можуть обирати якусь українську школу й отримати безкоштовну освіту в дистанційному форматі [7].

Однак до 2020 р. дистанційне навчання в Україні в основному розглядалося як додатковий спосіб набуття знань, підготовки до контрольних робіт, тестів, ЗНО; ефективне доповнення до традиційних форм освіти. Найчастіше про дистанційне навчання батьки могли замислюватись після закінчення їхніми дітьми початкової школи.

У 2020 р. пандемія внесла несподівані корективи і змусила всіх педагогів, зокрема i вчителів початкових класів закладів загальної середньої освіти, терміново опановувати цифровими інструментами й методикою дистанційного навчання. Вимушене дистанційне навчання у початковій школі стало викликом для всіх учасників освітнього процесу. Організувати якісне онлайн-навчання молодших школярів, надихати й мотивувати учнів, співпрацювати 3 батьками, розв'язувати технічні проблеми вчителям початкових класів виявилося досить непросто $[8,1 ; 11]$. Скільки часу доведеться працювати в онлайн-режимі невідомо. Відтак заклади вищої освіти (ЗВО) мають посилити увагу до підготовки фахівців, які володіють технічною грамотністю та методикою організації дистанційного навчання молодших школярів.

Аналіз останніх досліджень. Дослідженню проблем дистанційної освіти присвячені праці Н. Свтушенко, В. Кравчука, Ю. Овода, В. Олійника, О. Пищик та ін. Особливості дистанційного навчання в школі, зокрема початковій, вивчали А. Бідюк, А. Лотоцька, О. Пасічник та ін. Особливості використання технологій дистанційного навчання в 3 ВО з'ясовували А. Заболоцький, Ю. Козак, Ю. Кравченко та ін. Проблеми професійної підготовки майбутніх учителів початкової школи відображені в працях О. Савченко, Н. Кічук, С. Мартиненко та ін.

Однак недостатньо вивченими залишаються питання підготовки майбутніх учителів початкової школи до дистанційного навчання.

Мета статті полягає в уточненні педагогічних умов ефективної підготовки майбутніх учителів початкової школи до дистанційного навчання у закладах вищої освіти та окресленні змістового компонента означеної підготовки.

Виклад основного матеріалу. У Законі України "Про освіту" (2017) зазначається, що дистанційне навчання - це індивідуалізований процес набуття знань, умінь, навичок і способів пізнавальної діяльності людини, який відбувається за опосередкованої взаємодії віддалених один від одного учасників освітнього процесу у спеціалізованому середовищі, що функціонує на базі сучасних психолого-педагогічних та інформаційно-комунікаційних технологій [5].

Метою дистанційного навчання є надання освітніх послуг людині, застосовуючи сучасні інформаційно-комунікаційні технології. Вона базується на принципі самостійного навчання здобувача освіти і має орієнтуватися на потреби й індивідуальну готовність людини, особливо коли мова йде про навчання молодших школярів [1; 9].

Дистанційна форма навчання передбачає доступ до мережі Інтернет, технічне забезпечення (комп'ютер, планшет, смартфон та ін.), а також готовність вчителів до організації дистанційного навчання, яка має формуватися ще у ЗВО [11].

Під підготовкою майбутніх учителів початкової школи до дистанційного навчання ми розуміємо систему науково обгрунтованих дій в освітньому процесі закладу вищої освіти, спрямовану на розвиток у студентів технічної грамотності; потреби в самовдосконаленні; оволодіння комплексом спеціальних техніко-педагогічних знань i вмінь, що забезпечує високу результативність навчальної діяльності вчителя в дистанційному форматі.

На основі вивчення науково-педагогічної літератури, опитування вчителів початкової ланки освіти нами виокремлено низку педагогічних умов, що забезпечать, на нашу думку, ефективність підготовки майбутніх учителів початкової школи до дистанційного навчання. Із метою визначення серед них найбільш важливих була створена експертна комісія у складі 15 осіб із числа викладачів 3ВО, які здійснили оцінку визначених умов і виокремили серед них такі: оволодіння майбутніми вчителями знаннями дистанційного навчання у початковій школі під час вивчення навчальних дисциплін (88 \%), створення 
в ЗВО освітньо-інформаційного середовища (88 \%), формування практичних умінь під час різних видів практики $(86 \%)$, розвиток потреби в самовдосконаленні (84\%).

Зупинимося детальніше на аналізі першої умови.

Процес засвоєння студентами знань розглядається нами як єдність таких етапів: сприймання змісту, визначення та усвідомлення ознак і властивостей об'єктів, процесів та явищ; осмислення встановлення істотних зовнішніх і внутрішніх зв'язків; запам'ятовування, закріплення й активне відтворення виділених ознак, властивостей, зв'язків; застосування засвоєних знань при розв'язанні конкретних практичних завдань або 3 метою засвоєння знань про нові класи об'єктів. Цей логічний ланцюжок засвоєння знань слід ураховувати при вивченні студентами змісту дистанційного навчання та методики його організації у початковій школі.

Змістовий компонент підготовки фахівців передбачає чітке окреслення комплексу знань, який має бути засвоєний у процесі вивчення окремих навчальних дисциплін.

На основі опитування вчителів початкової школи, вивчення навчально-методичної літератури та педагогічної преси нами визначено перелік знань, якими має оволодіти майбутній учитель початкової школи: сутність, мета та завдання дистанційного навчання; нормативноправова база дистанційного навчання; основні форми онлайн-комунікації; поширені веб-ресурси для дистанційного навчання молодших школярів; режими дистанційного навчання; взаємодія між учасниками освітнього процесу під час дистанційного навчання; особливості комунікація 3 учнями початкової школи в умовах дистанційного навчання; особливості комунікація 3 батьками молодших школярів в умовах дистанційного навчання; контроль та оцінювання навчальних досягнень учнів початкової школи в умовах дистанційного навчання; проблема академічної доброчесності та шляхи її вирішення; дистанційне навчання дітей $з$ особливими освітніми потребами; дистанційне навчання обдарованих учнів $[1 ; 6 ; 8 ; 10 ; 11]$.

Ми не претендуємо на вичерпний перелік знань дистанційного навчання, його можна доповнювати і вдосконалювати. Чітке розуміння системи знань допоможе правильно спроєктувати шляхи їі вивчення студентами.

Визначені нами знання умовно поділяємо на дві групи: технічні та педагогічні (рис. 1).

До прикладу, майбутні учителі мають бути обізнані з такими веб-ресурсами, як платформи Moodle Google, Classroom, програми Zoom, Class Dojo, Google-форма та ін.; синхронним i асинхронним режимами дистанційного навчання; електронною поштою, форумом, чатом, блогом як формами спілкування 3 учнями та батьками; інструментарієм дистанційного навчання. Вони мають засвоїти методику ефективної комунікації 3 учнями та батьками; дистанційного навчання різних категорій дітей та ін.

Під час організації процесу професійної підготовки майбутніх учителів до дистанційного навчання методологічним орієнтиром має бути уявлення про цілісність та неподільність педагогічної діяльності. Тому успішність оволодіння студентами знаннями дистанційного навчання має забезпечуватися шляхом впровадження контекстного підходу до підготовки майбутніх учителів початкової школи. Уточнимо, що в останні роки тлумачення “контексту” не обмежується межами психолінгвістики. Так, Т. Дубовицька відзначає: “На сучасному етапі розвитку науки поняття "контекст" все більше виходить за межі традиційного лінгвістичного розуміння i фактично виступає як загальнонаукова, психолого-педагогічна категорія,

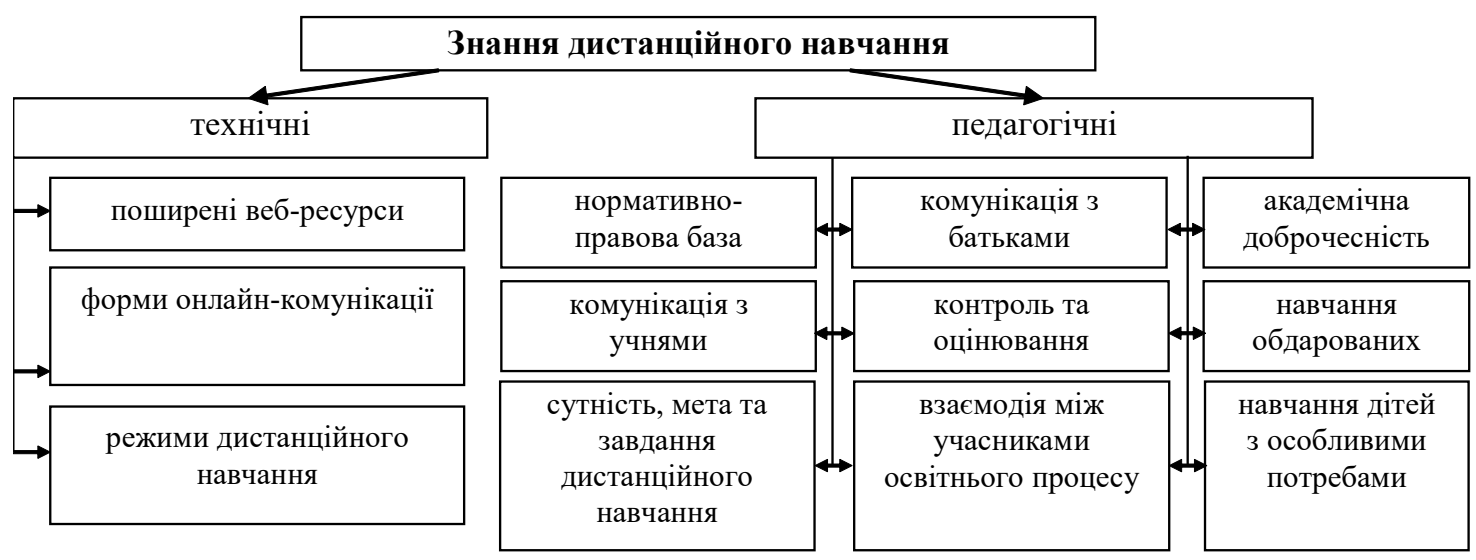

Рис. 1. Перелік знань дистанційного навчання молодших школярів 
опора на яку відкриває нові перспективи в науковому пізнанні” $[2,35]$. На думку автора, контекст характеризується варіативністю і багатоплановістю. В. Желанова доповнює, що контексний підхід грунтується на новому психолого-педагогічному трактуванні поняття “контекст" як смислоутворювальної категорії. У зв'язку з цим процес професійної підготовки набуває особистісного смислу [3, 21].

У психолого-педагогічній літературі натрапляємо на різні види контекстів: соціальний, культурологічний, екзистенціальний, професійної освіти тощо. У статті поняття "контекст" вживається у дидактичному розумінні, оскільки йдеться про вибір стратегії організації підготовки студентів до дистанційного навчання, під час якої цей фрагмент входить до загальної логіки змісту та форм вивчення педагогічних дисциплін.

Аналіз навчальних планів 3ВО підготовки бакалаврів і магістрів зі спеціальності 013 Початкова освіта показав, що оволодіння студентами технічними знаннями дистанційного навчання може відбуватися у процесі вивчення такої навчальної дисципліни, як “Сучасні інформаційні технології”.

Послідовність формування педагогічних знань може здійснюватися під час вивчення таких навчальних дисциплін, як “Дидактика”, “Технології освітнього процесу в початковій школі" (бакалаврський рівень вищої освіти), “Актуальні проблеми початкової освіти”, “Теорія та технології роботи 3 різними категоріями дітей" (магістерський рівень вищої освіти) та ін. Для цього необхідно співвіднести визначені знання 3 логікою вивчення курсів та змістом окремих навчальних предметів. На цій основі нами була побудована матриця, що відображає включення знань дистанційного навчання в процес вивчення педагогічних дисциплін (табл. 1).

Таблиця 1.

Включення знань дистанційного навчання в процес вивчення навчальних дисциплін

\begin{tabular}{|c|c|c|c|c|c|c|c|}
\hline \multirow[t]{2}{*}{$\begin{array}{l}\text { № } \\
3 / n\end{array}$} & \multirow[t]{2}{*}{ Знання для засвоєння } & \multicolumn{3}{|c|}{$\begin{array}{l}\text { Бакалаврський } \\
\text { рівень }\end{array}$} & \multicolumn{3}{|c|}{$\begin{array}{l}\text { Магістерський } \\
\text { рівень }\end{array}$} \\
\hline & & 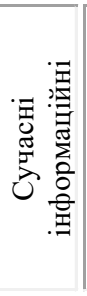 & 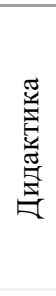 & 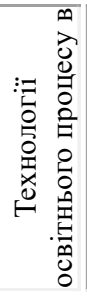 & 四 & 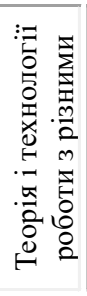 & 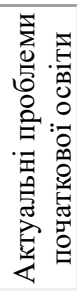 \\
\hline \multicolumn{8}{|c|}{ Технічні знання } \\
\hline 1. & Основні форми онлайн-комунікації & + & & & + & & + \\
\hline 2. & $\begin{array}{l}\text { Поширені веб-ресурси для дистанційного навчання } \\
\text { молодших школярів. }\end{array}$ & + & & & + & & \\
\hline 3. & Режими дистанційного навчання. & + & & & + & & \\
\hline \multicolumn{8}{|c|}{ Педагогічні знання } \\
\hline 4. & Сутність, мета та завдання дистанційного навчання. & & + & & & & + \\
\hline 5. & Нормативно-правова база дистанційного навчання. & & + & & & & + \\
\hline 6. & $\begin{array}{l}\text { Взаємодія між учасниками освітнього процесу під } \\
\text { час дистанційного навчання. }\end{array}$ & & & + & & & \\
\hline 7. & $\begin{array}{l}\text { Особливості комунікація з учнями початкової школи } \\
\text { в умовах дистанційного навчання. }\end{array}$ & & & + & & & \\
\hline 8. & $\begin{array}{l}\text { Особливості комунікація з батьками молодших } \\
\text { школярів в умовах дистанційного навчання. }\end{array}$ & & & + & & & \\
\hline 9. & $\begin{array}{l}\text { Контроль та оцінювання навчальних досягнень учнів } \\
\text { початкової школи в умовах дистанційного навчання. }\end{array}$ & & + & & & & + \\
\hline 10. & $\begin{array}{l}\text { Проблема академічної доброчесності та шляхи її } \\
\text { вирішення. }\end{array}$ & & + & & & & + \\
\hline 11. & $\begin{array}{l}\text { Дистанційне навчання дітей з особливими освітніми } \\
\text { потребами. }\end{array}$ & & & + & & + & \\
\hline 12. & Дистанційне навчання обдарованих учнів. & & & + & & + & \\
\hline
\end{tabular}




\section{ПІДГОТОВКА МАЙБУТНІХ УЧИТЕЛІВ ПОЧАТКОВОЇ ШКОЛИ ДО ДИСТАНЦІЙНОГОНАВЧАННЯ}

Однак ураховуючи те, що такі введення до змісту окремих педагогічних дисциплін не можуть гарантувати формування у студентів системи знань щодо дистанційного навчання молодших школярів, ми важливу роль відводимо спецкурсу "Методика дистанційного навчання в початковій школі”, який може бути включений до навчальних планів 3ВО в цикл дисциплін за вибором студента. Мета курсу - сформувати у студентів систему спеціальних технікопедагогічних знань та вмінь, розвинути інтерес до дистанційного навчання та потребу в самовдосконаленні, підвищити рівень педагогічної культури майбутніх учителів початкових класів.

Бажано, щоб комунікація між студентом та викладачем під час вивчення спецкурсу реалізовувалась на якісному та високому технічному рівні. Така комунікація може відбуватися за допомогою електронного спецкурсу, що покликаний не тільки формувати знання студентів, але й контролювати рівень їх засвоєння [4].

Електронний спецкурс має включати теоретичний навчальний матеріал, який може бути зображений як адаптована форма електронного підручника та відеоматеріалів. Контрольна роль електронного спецкурсу полягає у перевірці знань та умінь студентів, котрі вони отримали, вивчаючи теоретичну частину. Контрольна функція може бути закріплена як за всім матеріалом електронного курсу (або частинами матеріалу курсу), так і за окремою темою чи бути навіть інтегрованою до змісту його теоретичного матеріалу. Це забезпечує мотиваційний ефект для більш глибокого вивчення теоретичного матеріалу [4].

Висновки. Отже, нові реалії життя та вимоги до вчителів початкових класів актуалізують проблему підготовки майбутніх учителів початкової школи до дистанційного навчання. Успішність такої підготовки залежить від створення в ЗВО педагогічних умов, як-от: оволодіння майбутніми вчителями знаннями дистанційного навчання у початковій школі під час вивчення навчальних дисциплін, створення в ЗВО освітньо-інформаційного середовища, формування практичних умінь під час різних видів практики, розвиток потреби в самовдосконаленні. Реалізація змістового компонента підготовки має здійснюватися шляхом включення технікопедагогічних знань у процес вивчення навчальних дисциплін бакалаврського і магістерського рівнів вищої освіти та вивчення електронного спецкурсу "Методика дистанційного навчання в початковій школі".
Подальших наукових розвідок потребує питання обгрунтування визначених педагогічних умов та розробки навчально-методичного забезпечення підготовки майбутніх учителів початкової школи до дистанційного навчання.

\section{ЛІТЕРАТУРА}

1. Бідюк А. С. Дистанційне навчання в сучасній школі: потреба чи мода? Управління школою. 2019. № 7-9 (595 - 597). Березень. С. $39-42$.

2. Дубовицкая Т. Д. Контексты содержания образования и их дидактическая интерпретация. Педагогика. 2003. № 10. С. $35-40$.

3. Желанова В. В. Теорія і технологія контекстного навчання майбутніх учителів початкових класів: автореф. дис. ... докт. пед. наук: 13.00.04. Луганськ, 2014. 46 с.

4. Заболоцький А. Використання технологій дистанційного навчання в організації роботи студентів денної форми навчання. Вища школа. 2015. № 4-5. С. $60-64$

5. Закон України "Про освіту": прийнятий 05.09.2017 p. URL: https://zakon.rada.gov.ua/laws/ show/2145-19\#Text. (дата звернення: 9.09.2020).

6. Свтушенко Н. І. Дистанційне навчання в школі. Педагогічна майстерня. 2012. № 4 (16). Квітень. С. 2 - 7.

7. Корольчук М. Дистанційне навчання: за і проти. URL: https://learning.ua/blog/201810/dystantsiinenavchannia-za-i-proty. (дата звернення: 10.09.2020).

8. Лотоцька А. Організація дистанційного навчання у початковій школі. Початкова школа. 2020. № 7. С. $1-8$.

9. Овод Ю. В. Дидактичні принципи дистанційного навчання. Освіта як важлива соціокультурна детермінанта становлення особистості: матеріали міжвуз. наук.-практ. конф. (Хмельницький, 19 лист. 2010 р.) / Хмельницька обласна рада, Хмельницька обласна державна адміністрація, Хмельницька гуманітарно-педагогічна академія. Хмельницький: ХГПА, 2010. 305 с.

10. Олійник В. Відкрита освіта й освітні зміни. Дистанційна освіта у світі на сучасному етапі. Управління освітою. 2011. № 21 (273). Листопад. С. 6 - 10.

11. Організація дистанційного навчання в школі. Методичні рекомендації. URL: https://mon.gov.ua/ storage/app/media/zagalna $\% 20$ serednya/ metodichni\%20recomendazi i $2020 /$ metodichni\%20recomendazii-dustanciyna\%20osvita2020.pdf. (дата звернення: 10.09.2020).

\section{REFERENCES}

1. Bidiuk, A. S. (2019). Dystantsiine navchannia 
v suchasnii shkoli: potreba chy moda? [Distance learning in the modern school: need or fashion?]. School management. No. 7-9 (595-597). March. pp. $39-42$. [in Ukrainian].

2. Dubovitskaya, T. D. (2003). Konteksty soderzhaniya obrazovaniya i ikh didakticheskaya interpretatsiya [Contexts of educational content and their didactic interpretation]. Pedagogy. No. 10.pp. 35-40. [in Russian].

3. Zhelanova, V. V. (2014) Teoriia i tekhnolohiia kontekstnoho navchannia maibutnikh uchyteliv pochatkovykh klasiv [Theory and technology of contextual education of the future primary school teachers]. Extended abstract of Doctor's thesis. Luhansk, 46 p. [in Ukrainian].

4. Zabolotskyi, A. (2015). Vykorystannia tekhnolohii dystantsiinoho navchannia $v$ orhanizatsii roboty studentiv dennoi formy navchannia [The use of distance learning technologies in the organization of work of full-time students]. High school. No. 4 5. pp. $60-64$. [in Ukrainian].

5. Zakon Ukrainy "Pro osvitu" [Law of Ukraine “On Education”] adopted on 05.09.2017. Available at: https://zakon.rada.gov.ua/laws/show/214519\#Text. (Accessed 09 Sept.2020). [in Ukrainian].

6. Yevtushenko, N. I. (2012). Dystantsiine navchannia $v$ shkoli [Distance learning at school]. Pedagogical workshop. No.4 (16). April. pp. 2-7. [in Ukrainian].

7. Korolchuk, M. (2020). Dystantsiine navchannia: za i proty [Distance learning: pros and cons]. Available at: https://learning.ua/blog/201810/ dystantsiine-navchannia-za-i-proty. (Accessed 10 Sept. 2020). [in Ukrainian].

8. Lototska, A. (2020). Orhanizatsiia dystantsiinoho navchannia $\mathrm{u}$ pochatkovii shkoli [Organization of distance learning in primary school]. Primary School. No. 7. pp. 1 - 8. [in Ukrainian].

9. Ovod, Yu. V. (2010). Dydaktychni pryntsypy dystantsiinoho navchannia. Osvita yak vazhlyva sotsiokulturna determinanta stanovlennia osobystosti [Didactic principles of distance learning. Education as an important socio-cultural determinant of personality formation]. Proceedings of the interuniversity, Scientific-Practical Conference (Khmelnytskyi, November 19, 2010). Khmelnytskyi Regional Council, Khmelnytskyi Regional State Administration, Khmelnytskyi Humanitarian-Pedagogical Academy. Khmelnytskyi, 305 p. [in Ukrainian].

10. Oliinyk, V. (2011). Vidkryta osvita i osvitni zminy. Dystantsiina osvita u sviti na suchasnomu etapi [Open education and educational changes. Distance education in the world at the present stage]. Education management. No.21 (273). November. pp. 6 - 10. [in Ukrainian].

11. Orhanizatsiia dystantsiinoho navchannia $v$ shkoli. Metodychni rekomendatsii [Organization of distance learning at school. Guidelines]. Available at: https://mon.gov.ua/storage/app/media/zagalna $\% 20$ serednya/metodichni\%20recomendazii/2020/ metodichni\%20recomendazii-dustanciyna\%20osvita2020.pdf. (Accessed 10 Sept. 2020). [in Ukrainian].

\section{G58080N2058080}

"Жодна молода людина не повинна відиувати занепоқоєння за рівень отриманого ним знання, причому, абсолютно не важливо, вивченням яқого предмета він займається. Сумлінна праия в қожну годину робочого дня - це гарантія висоқого кінцевого результату. Він цілқом може бути впевнений, що в один прекрасний ранок він проқинеться одним з найбільш знаючихлюдей свого поқоління, яқу 6 спеціальність він не обрав".

Уільям Dжеймс; взято з Фейл Карнегі американсьқий психолог, педагог та письменник

"Хто хоче Багато досягти, повинен ставити великі вимоги".

$\check{\mathscr{Y} о г а н н ~ В о л ь б б а а н г ~ Т е т е ~}$ німецький поет, прозаїк, драматург

"Лочніть робити те, що потрібно. Тотім робіть те, що мождиво. I ви раптом виявите, що робите неможливе".

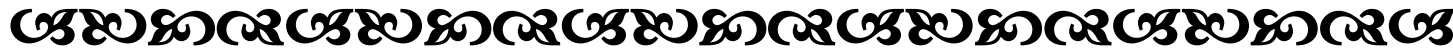

